Article received on November $4^{\text {th }} 2020$

Article accepted on November $30^{\text {th }} 2020$

Original scientific paper

UDC: 78.071.1(497.11)

78.071.1:929 Марић љ.

\author{
Melita Milin* \\ Institute of Musicology \\ Serbian Academy of Sciences and Arts, Belgrade
}

\title{
MONOGRAPHS ON COMPOSERS AS A MUSICOLOGICAL GENRE ${ }^{1}$
}

\begin{abstract}
Monographs on composer may considerably diverge from one another, depending on their authors' fundamental views concerning the way and extent to which biographical data should be used in relation to music analysis. So as not to lapse into mere music Biographik, a monograph should encompass the life and works of its subject in a complementary way - with all the necessary contextualization - and bring them into a meaningful relationship in a well thought-out and critical manner. That ideal goal should be pursued, although usually the result is a more or less successful hybrid of a biography and music analysis.
\end{abstract}

Keywords: monographs on composer, Serbian composer monographs, monograph on Ljubica Marić, music analysis and biography, self-referentiality of musical works

Expressing my gratitude for awarding me this prize of the Serbian Musicological Society, not only to the Institute of Musicology at the Serbian Academy of Sciences and Arts, which nominated my monograph for the Award, but also to the members of the Jury who made the decision, I wish to express how happy I am that the Society decided, with no dilemma at all, that this newly established award, the first in our humanist discipline, should be named after Stana Đurić-Klajn, one of the pioneers of Serbian musicology, a visionary fig-

* Author contact information: melita_milin@yahoo.com

1 Acceptance speech given at the presentation ceremony of the 2018 "Stana Đurić-Klajn" Awards of the Serbian Musicological Society, Music Gallery of the Kolarac Endowment, 15 October 2020. 
ure who left a deep trace in the history of Serbian and Yugoslav musicology and writing on music. I did not have the opportunity to witness Prof. Klajn's qualities as a teacher and had to rely instead on my colleagues' accounts, because by the time of I enrolled at the Academy of Music in Belgrade, she had already retired as a professor and when I began working at the Institute of Musicology of the Serbian Academy of Sciences and Arts several years later, she had retired from there, too, where she had served as a research fellow and director. That is why, unfortunately, I never had an opportunity to get to know her more closely, as a person. The first time I met her was when the Institute's newly appointed director, the late Dimitrije Stefanović, asked me to pay her a visit at a hospital in Belgrade where she was receiving treatment and I saw her another two or three times later, when she came to visit the Institute. I was honoured to co-edit, along with Mirjana Veselinović-Hofman (the other laureate of this award, in the lifetime achievement category), the proceedings of an academic conference dedicated to Klajn (2008) ${ }^{2}$ and thus make a professional homage to her as a renowned scholar who produced a rich oeuvre.

My monograph, љубииа Марић: комйоноваюе као іраяииельски чин (Ljubica Marić: Composing as an Act of Creation), is an addition to the relatively short list of Serbian publications in this genre of musicology. Although Kosta Manojlovićs Сйоменица Сиевану Мокрағииу (A Memorial to Stevan Mokranjac, 1923) was modest in scope, it might be labelled the first monograph in our musicology and the only one published in the interwar period. The post-WWII years saw Petar Konjovićs important monographs on Miloje Milojević (1954) and Stevan Mokranjac (1956), ${ }^{3}$ followed by similar works that became vital in the study of Serbian music ${ }^{4}$ - Vlastimir Peričićs mono-

2 The conference took place on 5-6 December 2008 at the Music Information Centre in Belgrade, while the proceedings were published the following year: Мирјана Веселиновић-Хофман [Mirjana Veselinović-Hofman] and Мелита Милин [Melita Milin] (eds), Сйана Ђурић-Клајн и срӣска музиколоїија. Повоgом сйоїодишњице рођень Сйане Ђурић-Клајн (1908-1986) [Stana Đurić Klajn and Serbian Musicology: On the Centenary of the Birth of Stana Đurić-Klajn (1908-1986)], Belgrade, Serbian Musicological Society, 2010.

3 Петар Коњовић, Милоје Милојевић, комӣозит̄ор и музички йисаи [Miloje Milojević, Composer and Writer on Music], Belgrade, Serbian Academy of Sciences, Department of Fine Arts and Music, 1954); Сйеван Сй. Мокранаи, [Stevan St. Mokranjac], Belgrade, Nolit, 1956.

4 In the words of Ivana Ilić, the 1960s and 1970s were "the golden age' of composer monographs..., in "Auto/biographical Discourse in Serbian Musical Periodicals (1993- 
graphs on Josif Marinković (1967) and Stanojlo Rajičić (1971), ${ }^{5}$ and Marija Koren (Bergamo)'s work on Milan Ristić $(1977)^{6}$ and Nadežda Mosusova's book on Petar Konjović. 7 Toward the end of the $20^{\text {th }}$ century there came another monograph study: Mirjana Veselinović-Hofman's work on Vladan Radovanović (1991). ${ }^{8}$ The beginning of this century saw the publication of Gorica Pilipovićs monograph on Dušan Radić $(2000)^{9}$ and, several years later, Enriko Josif's monograph on Milenko Živković, published posthumously in $2009,{ }^{10}$ the same year that my monograph publication about Ljubica Marić came out as an extended catalogue accompanying the exhibition I curated at the Gallery of the Serbian Academy of Sciences and Arts in 2009, foreshadowing the 'real' monograph published nine years later. ${ }^{11}$ Nemanja Sovtićs monograph on Rudolf Brucci (Вruči; Бручи) was published on the composer's centenary in 2017, while the latest monograph to come out in our rapidly growing musicological literature is dedicated to Predrag Milošević (2019),

2007): The Positioning of the Female Voice", in: Tatjana Marković \& Vesna Mikić (eds), (Auto) Biography as a Musicological Discourse, Belgrade, Department of Musicology, Faculty of Music \& University of Arts in Belgrade, 2010, 184.

${ }_{5}^{5}$ Властимир Перичић, Јосиф Маринковић - живой и gела [Josif Marinković: Life and Works], Belgrade, Serbian Academy of Sciences and Arts, 1967 and Stvaralački put Stanojla Rajičića [The Creative Path of Stanojlo Rajičić], Belgrade, Academy of the Arts, 1971.

${ }^{6}$ Marija Bergamo, Delo kompozitora: Stvaralački put Milana Ristića od prve do šeste simfonije [A Composer's Oeuvre: The Creative Journey of Milan Ristić from the First to the Sixth Symphony], Belgrade, University of Arts, 1977.

7 This book is still in manuscript and its publication is forthcoming.

${ }^{8}$ Mirjana Veselinović, Umetnost i izvan nje. Poetika i stvaralaštvo Vladana Radovanovića [Art and Beyond: The Poetics and Creativity of Vladan Radovanović], Novi Sad, Matica srpska, 1991.

9 Горица Пилиповић, Поілеg на музику Душана Paguћa [A Survey of the Music of Dušan Radićc], Belgrade, Serbian Academy of Sciences and Arts, 2000.

${ }^{10}$ Енрико Јосиф, Миленко Живковић ["Milenko Živković"], Belgrade, Department of Fine Arts and Music of the Serbian Academy of Sciences and Arts, 2009.

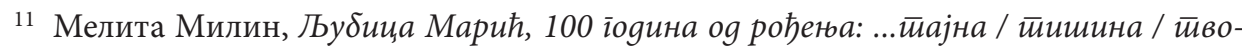
perbe... [Ljubica Marić: $100^{\text {th }}$ Anniversary of the Birth: Mystery, Silence, Creation], Serbian Academy of Sciences and Arts (Gallery of the Serbian Academy of Science and Arts, No. 116), Belgrade, 2009 and љубица Марић - Комӣоновате као іраяииеељски чин [Ljubica Marić: Composing as an Act of Creation], Belgrade, Institute of Musicology at the Serbian Academy of Sciences and Arts, 2018. 
authored by Jelena Mihajlović Marković. ${ }^{12}$ A more detailed analysis of Serbian composers monographs would also need to take into account the following studies that came out in hectograph, smaller in scope but still significant as valuable contributions to Serbian music history: Dejan Despić, Marko Tajčević (Serbian Composers' Association, Belgrade, 1972) and Mirjana Veselinović, Milivoje Crvčanin (Serbian Composers' Association, Belgrade, 1972). Also, such a list would need to include Jelena Milojković Đurić's article "Kosta P. Manojlović u međuratnom razvoju muzičke kulture" (Kosta Manojlović and the Development of Musical Culture in the Interwar Period), published in V. Peričić (ed.), U spomen Koste P. Manojlovića (In Memoriam Kosta Manojlović, Belgrade: Faculty of Music, 1990), 7-100. A comprehensive index of monograph publications on Serbian composers should also include undergraduate and graduate final theses presented at our institutions of higher education in music.

These monograph studies of Serbian composers are quite varied in conception, which may relate to the differing scopes and characters of the oeuvres they address, as well as their authors' personal views and the standards of the times and the institutions that published them. In the opening chapters of his monographs on Milojević and Mokranjac, Konjović traces their biographies continually, concluding with their return from studies abroad and establishment in the musical life of Belgrade and beyond, with brief discussions of their early works from those periods in their career. The monograph on Mokranjac proceeds with an analytical focus on his works, occasionally including, where needed, information on relevant events from his professional life as a conductor and pedagogue. With regards to the more diverse and quantitatively much more prolific pursuits of Miloje Milojević, the relevant chapters of his monograph are both larger in scope and more detailed. In the concluding sections of both books, Konjović offers not only an assessment of the significance of their respective oeuvres, but also an intimate portrait of both composers, whether by quoting from the memories of their contemporaries, in the case of Mokranjac, or by relaying his own memories and observations, since, as we know, he was a friend of Milojević, which thus provided another layer in his portrayal of the composer's personality.

In his monograph on Josif Marinković, Vlastimir Peričić divides his 'Life' and 'Works' into clearly delineated chapters, both of them minutely elaborate,

12 Jelena Mihajlović Marković, Predrag Milošević - Portret muzičkog stvaraoca [Predrag Milošević: A Portrait of a Creator in Music], Belgrade, Institute of Musicology at the Serbian Academy of Sciences and Arts and Serbian Musicological Society, 2019. 
exquisitely supported by facts, and transparently structured; moreover, such a division, entirely justified, was at least partly dictated by the difficulty of dating the composer's works, which would have made it hard to link events from his private/professional life with his works. Similarly to the monographs discussed above, it sheds light on the composer's personality as well - in a separate and smaller subchapter - based on oral and written accounts from his descendants and acquaintances.

Peričićs other monograph is dedicated to his professor Stanojlo Rajičić, who was 61 when it came out and who, as we know, lived for another three decades thereafter and remained creatively active throughout. Peričić structured his narrative chronologically, focusing mainly on the most important works, providing them with analytical commentary including a wealth of notated examples, while other pieces were only mentioned in passing. Snippets of biographical information - for instance, regarding Rajičić's childhood and first lectures in music, his studies in Prague, Belgrade's musical life during the late 1930s, Rajičićs polemic with Svetomir Nastasijević - are built into the tissue of Peričićs text with conciseness and a clear sense of purpose. In the Introduction to her book on the oeuvre of Milan Ristić (1977), ${ }^{13}$ Marija Bergamo notes that she did not write a standard monograph because the composer's oeuvre was not yet complete, as well as because not enough time had passed since the latest stylistic changes in Ristićs oeuvre. Bergamo focused on positioning the composer's work in relation to his working environment in Yugoslavia as well as on drawing links with stylistic directions in European music, with the final chapter summarizing Bergamo's analyses of his symphonic music, while "A Short Biography" is included as an appendix.

Mirjana Veselinović-Hofman refers to her book on the poetics and oeuvre of Vladan Radovanović as a study (which appears in its subtitle as well), ${ }^{14}$ although one might broadly regard it as a monograph. On the one hand, it analyzes the whole of Radovanović's oeuvre thus far, encompassing not only his musical compositions, but also works in extra-musical domains and syntheses; on the other hand, one of the peculiarities of this book is that its subject's biography receives a total of a single footnote (no. 3), which communicates the kind of basic data one might find in an encyclopaedia, demonstrating the author's position regarding the (limited) value of relating a composer's works to his life.

${ }^{13}$ Marija Bergamo, Delo kompozitora. Stvaralački put Milana Ristića od Prve do Šeste simfonije, Belgrade, University of Arts, 1977.

14 M. Veselinović, Umetnost $i$ izvan nje, op. cit., 8. 
Although written as early as the 1970s, Josif's monograph on Milenko Živković was published only several years after his death, with necessary additions, thanks to the efforts of several highly competent and committed colleagues and friends. Similarly to Peričićs book on Rajičić, this monograph likewise has the added value of an act of homage to the author's professor of composition. As the monograph's editor, Dejan Despić wrote in his foreword that "every book of this kind speaks not only of the figure to whom it is dedicated, but also of its author" and, indeed, what we get is a book with a strong and vivid authorial mark, and yet also an informative and analytical book, with a short concluding chapter "In Memoriam", where Josif writes about his own personal memories of Živković as a man.

In line with his view that the post-socialist era has neglected Rudolf Brucci as a composer and that his cantatas and oratorios have been singled out as undesirable, Nemanja Sovtić advances in his monograph dedicated to this composer an array of arguments advocating a reappraisal of Brucci in our music historiography, especially as a composer, as well as a highly active organizer of and participant in musical life. That is why his monograph, in addition to its detailed analyses of individual works, which form the central part of his study, also presents a wealth of biographic material, used as the basis for an accurate portrayal of private and social aspects of the composer's personality and work. Thus in the opening chapter Sovtić advances his interpretations based on testimonies from Brucci's contemporaries about him as a person, his views and everyday life, while in a series of appendices at the end of the book he presents a selection of Brucci's writings and interviews.

The first five chapters of Jelena Mihajlović's monograph on Predrag Milošević offer a detailed life and works of the composer, including, in addition to events from his private life that were in various ways linked to music, a survey of individual stages in his education and later career in composing, conducting, teaching, and writing on music, without neglecting the socio-musical contexts of his activities. In the second, larger part of the book, Mihajlović aims her analytical attention to Miloševićs oeuvre as a whole, with a justifiable focus on his three most important works.

It is easy to see that these monograph studies address composers from the summit/canon of Serbian ${ }^{15}$ music, whether born in the 1850s or 1880s, whether belonging to the "Prague group" who came of age during the interwar peri-

${ }^{15}$ Leaving out Krešimir Baranović as a Croatian composer, the subject of Mirjana Veselinović-Hofman's monograph Krešimir Baranović: Stvaralački uspon, Zagreb, Jugoslavenska akademija znanosti i umjetnoti, 1979. 
od, with the exception of Vladan Radovanović, who belongs to a later generation born after World War I. One may also note that three of them were alive when their monographs appeared, which means that the fact that their oeuvres were not yet complete did not present an obstacle to their authors. Although in some disciplines of the humanities, such as art history, there is (or, at least, there used to be) a rule that monographs are only written about authors whose life and creative journey have ended, ${ }^{16}$ in musicology things were different. In that regard, there are written documents from the 1960s by members of the Department of Fine Arts and Music at the Serbian Academy of Sciences and Arts about plans to commission monographs on contemporary composers, members of the Academy, although not all of them were implemented. ${ }^{17}$

I would like to amend this brief survey of Serbian composer monographs with a reminder of what is so far the only monograph dedicated to a musicologist - Roksanda Pejović's book on, indeed, Stana Đurić-Klajn. ${ }^{18}$ Pejović begins her foreword by referring to her publication explicitly as a monograph, even though she addresses Klajn's biography merely in the opening three pages of the first chapter (up until 1941) and a few pages at the beginning of the second chapter (the post-WWII period). Thus in the first part of the book, in addition to tracing individual stages in Klajn's education as an aspiring writer on music and musicologist, as well as her efforts to find her true vocation, Pejović outlined, without going into much detail, the main trajectories of her professional biography, probably regarding that as a sort of necessary socio-historical contextualization of Klajn's work. We should also note several monographs dedicated to our performing musicians, most prominently the monograph on the opera singer Zlata Đunđenac (1990) by Irena Grickat, an important Serbian linguist and lexicographer. ${ }^{19}$

16 As told to the author by Dejan Medaković, a fellow of the Serbian Academy of Sciences and Arts.

17 See Биљана Милановић [Biljana Milanović], “Деловање музичара у оквиру Одељења ликовне и музичке уметности САНУ” [The Work of Musicians at the Department of Fine Arts and Music of the Serbian Academy of Sciences and Arts], 2017; to be published by the Serbian Academy of Sciences and Arts.

18 Роксанда Пејовић [Roksanda Pejović], Музиколог̄ Сӣана Ђурић-Клајн: исӣо-

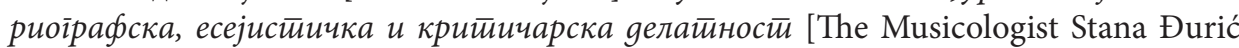
Klajn: Historiography, Essays, and Criticism], Belgrade: Serbian Academy of Sciences and Arts, Institute of Musicology at the Serbian Academy of Sciences and Arts and Serbian Composers' Association, 1994.

19 Ирена Грицкат [Irena Grickat], Злайа Бунђенаи, Belgrade: Serbian Academy of Science of Arts and Institute of Musicology at the Serbian Academy of Sciences and Arts, 
Viewed in retrospect, my path to writing a monograph on Ljubica Marić began when I decided to write my undergraduate final thesis, supervised by Prof. Vlastimir Peričić, about Marić's post-WWII oeuvre. This decision took me to the Institute of Musicology at the Serbian Academy of Sciences and Arts, to which Marić had bequeathed her collection of concert programmes and press clippings about her works, as well as a few texts published in periodicals and exhibition catalogues, or drafted for radio interviews. Later on, working on the monograph, I committed myself to producing a monograph that would be as comprehensive as possible, presenting Marić not only through her musical works - which was certainly my main concern - but also as an author of poetic and other types of texts, works in the visual arts, and a conductor, as well as a person. Due to the complex demands placed before authors of monographs, many of such works are criticized for focusing too much on biographical data and not enough on analysis or vice versa, as well as for failing to forge sufficiently compelling links between those two aspects or not making them relevant enough.

One should note here that for the most part, debates on the relevance of composer monographs for musicology were waged in the past, from the late $19^{\text {th }}$ century and for much of the $20^{\text {th }}$ century, in the academic circles of nations with long-standing traditions in music and musicology, whose rich bibliographies feature a large number of books in that genre targeting mostly a wider readership. These debates occurred mainly because in many of these monographs their biographical segments were often freely, uncritically related to the composer's oeuvre. Monographs were thereby consigned to a somewhat problematic place in music historiography and for a long time remained outside of the musical arena. ${ }^{20}$ One of musicology's founding fathers, Guido Adler, attached little value to the genre, dubbed Biographik, which makes sense when one takes into account the kinds of music monographs written in the $19^{\text {th }}$ century, which exaggerated the significance of musicians' lives, promoted the cult of genius, and were for the most part popular in style and character. As a new discipline in the humanities, musicology sought to position itself clearly as a serious scholarly discipline, thereby privileging as "the central paradigm of $20^{\text {th }}$-century musicology", according to Hermann Da-

1990. Equally noteworthy are the contributions of Vladimir Jovanović, who edited a publication on Nikola Cvejić (1994) and published a monograph on Gordana Jevtović Minov (2017).

20 Christopher Wiley \& Paul Watt, "Musical Biography in the Musicological Arena”, Journal of Musicological Research, 38/3-4, 2019, 187. 
nuser, "phenomenology, structuralism, and problem- or historically oriented music analysis, which resulted in separating 'life' from 'works', while the reception of Gadamer likewise weakened the links between biographism [Biographismus] and hermeneutics, turning the erstwhile complementary relation between these two disciplines into one of opposition". ${ }^{21}$ As the $20^{\text {th }}$ century drew to a close, the authors of composer monographs placed less and less emphasis on the autonomy of the musical work, instead observing it increasingly in historical, social, and stylistic relations, as well as from the perspective of music reception. That a series of outstanding monograph studies published throughout the $20^{\text {th }}$ century effected a rise in stature of the monograph as a genre of musicology is likewise suggested by the fact that the editors of the 2001 edition of the renowned New Grove Dictionary included for the first time an entry on biography, that is, music biography (as it is termed in Anglo-American musicology), stating, among other things, that the previous century had seen musicology's "ambivalent reconciliation with biography". ${ }^{2}$

Objections to the monograph as a genre, which have not entirely disappeared, are aimed, according to Jolanta Pekacz, at "the alleged lack of relevance of biographical knowledge to aesthetics and criticism, grounded in the belief that 'life' and 'works' are unrelated; that the meaning of a work is independent of its author's life". ${ }^{23}$ The view that facts and events from a composer's biography have little bearing on the interpretation of her/his music was shared by Carl Dahlhaus, although he did acknowledge that biographical research may occasionally be useful and even necessary in the interpretation of musical works, because some details about individual pieces may not be adequately explained without referring to certain data concerning the composer's life. "So there is no justification [according to Dahlhaus] for bringing a charge of aesthetic dereliction in those cases where it proves impossible to avoid the recourse to biography, or the history of the work's genesis, even if the principle of immanence suffers. The idea of a hermetically insulated, entirely self-referential existence for a work is the basis of the arguments against

${ }^{21}$ Hermann Danuser, "Biographik und musikalische Hermeneutik: Zum Verhältnis zweier Disziplinen der Musikwissenschaft”, in: Joseph Kuckertz et al. (eds), Neue Musik und Tradition: Festschrift Rudolf Stefan, Laaber, Laaber-Verlag, 1990, 570.

22 Maynard Solomon, "Biography," in: Stanley Sadie (ed.), The New Grove Dictionary of Music and Musicians, London, Macmillan, 2001, Vol. 3, 598-601.

${ }^{23}$ Jolanta Pekacz, "Musical Biography-Further Thoughts" in: Zdravko Blažeković and Barbara Dobbs Mackenzie (eds), Music's Intellectual History, New York, Répertoire International de la Littérature Musicale, 2009, 844. 
biographical procedures, but it is only a rule with a limited historical authority, not an immutable natural law of art: the relative legitimacy or illegitimacy of the biographical method depends partly on the nearness or remoteness of a work from classicist aesthetics. Epochs and genres of an 'objective' bent, such as classicism and drama in closed forms, are less accessible to biographical interpretation than those that can be called 'subjective', such as romanticism, and the lyric poetry of personal experience." ${ }^{24}$ Interestingly, Dahlhaus wrote these lines in the opening chapter ("Life and Work") of his monograph on Beethoven, discussing the biographical method in general, its internal form and external purposes, aesthetic and biographical subject, whereas in lieu of an introduction he supplied a brief chronology of important events in Beethoven's life. One of Dahlhaus's last works, bearing the unpretentious title of Ludwig van Beethoven und seine Zeit, it is original in its conception and merits a separate discussion.

Judging from monographs that are written today, there dominates a tendency to use select elements from the composer's life as signposts or basis for attempting to interpret their works. In that regard, a potentially illustrative example is another monograph on Beethoven, written by the English musicologist Barry Cooper (2000). ${ }^{25}$ The well known episode concerning Beethoven's removal of the dedication to Napoleon Bonaparte from the title page of his manuscript of the Third Symphony served, with justification, as an argument for separating art from politics - since the work stands with equal success as independent / freed from association with its author's political views. However, that event acquires a different meaning in light of Cooper's discovery that for several months after tearing up the dedication, Beethoven still maintained that the Symphony had been composed to honour Napoleon and that he was forced only by financial constraints to dedicate the work to Prince Lobkowitz in the end. ${ }^{26}$

Nonetheless, there still remain certain reservations about using composers' biographies in discussions of their musical works, stemming from the old debates on the question of music's autonomy, that is, the self-referentiality

24 Carl Dahlhaus, Ludwig van Beethoven: Approaches to his Music, Oxford, Oxford University Press, 1991, 2-3 [Ludwig van Beethoven und seine Zeit, Laaber, Laaber Verlag, 1987].

25 Barry Cooper, Beethoven, Oxford, Oxford University Press, 2000, 141.

26 This example was borrowed from Christopher Wiley's "Biography and the New Musicology”, in: Tatjana Marković and Vesna Mikić (eds), (Auto)Biography as a Musicological Discourse, Belgrade, Department of Musicology, Faculty of Music, 2010, 8. 
of musical works, as well as whether and to what degree elements from the extra-musical sphere participate in the constitution of their meanings. As we know, arguing for an autonomous status of the musical work relates to the concept of absolute music and informs the basis of modernist aesthetics, which means that upon the emergence of postmodernism such positions were bound to face increasing challenges.

To be sure, it is not only composers biographies that belongs in the extra-musical domain, but also their cultural and social contexts, which in turn exert a strong impact on biographies and are seldom questioned. In that sense it is really difficult to defend the claim that 'life' and 'work' are unrelated and that a musical work exists 'by itself'. I would therefore agree with the view of Maynard Solomon, incidentally the author of another Beethoven monograph, that if biographical data are available, they certainly affect whether we like it or not - our aesthetic and cultural assessments, modifying our perceptions of art, just as our knowledge of history and other cultural phenomena does. ${ }^{27}$ This, of course - although it hardly needs stating - does not concern drawing naïve links between anecdotal events from a composer's life with concrete musical and technical procedures, or suggesting the existence of some 'hidden programmes' in certain pieces (here we should think of the reliability, that is, problematic character of such 'readings' of certain works by Tchaikovsky, Shostakovich, and many others). After a long hiatus in interpretations like these, the deconstructivist tendencies that developed in musicology (especially in Anglo-American musicology) from the early 1980s on brought attempts at making hermeneutical inroads into the domain of musical creativity from the perspectives of gender, sexuality, race, class, and ideology. ${ }^{28}$ However, this switch from a positivistic approach to the lives and works of composers occasionally resulted in drawing some problematic links between certain details from composers' lives and their pieces, with especially bizarre consequences in works by Susan McClary. ${ }^{29}$

Today, it is almost taken for granted that a composer monograph should cover both life and works. But the question is - and it is an essential question

\footnotetext{
27 Maynard Solomon, “Thoughts on Biography”, 19th-Century Music, 5/3, Spring 1982, 273.

28 For more on this, see Wiley, op. cit.

29 Susan McClary, "Constructions of Subjectivity in Franz Schubert's Music", in: Philip Brett, Elizabeth Wood, and Gary Thomas (eds), Queering the Pitch: The New Gay and Lesbian Musicology, New York, Routledge, 1994; Susan McClary, Feminine Endings: Music, Gender, and Sexuality, Minneapolis, University of Minnesota Press, 2002.
} 
- how? Summarizing his own experiences of working on monographs, the renowned musicologist Jim Samson has written about the difficulties he faced trying to integrate as best he could the lives and works of composers, concluding that there is no universal solution for constructing a specific methodology that would enable this. In the introduction to one of his two Chopin monographs (he also wrote one on Szymanowski), Samson formulated his position in the following terms: "Too little is yet known about the mental processes involved in composition to allow any but the most obvious connections to be made [between a composer's biography and oeuvre]. Since we are not (I suggest) in a position to attempt a thorough integration of 'life' and 'works', we had better accept the hybrid character of this genre [composer biographies, that is, monographs]. It remains, and it probably should remain, [as] two books in one". 30

Returning to my own monograph, I want to stress here that it would have been rather difficult to reconstruct the life of Ljubica Marić (who was seldom willing to say anything about it, whether in private or in interviews), had it not been for her extant legacy, comprising various family documents and correspondence. I believe that the composer did not destroy them chiefly because they concern her mother, who occupied a unique place in her life. I also found a small number of documents in other places. The archive of the Gymnasium in Valjevo still has her grade-books from the two years she spent there, with descriptive observations by her teachers concerning the extraordinary capabilities of this student who simultaneously took violin lessons from the music teacher at the same school. ${ }^{31}$ In the Archives of Serbia I found almost nothing, except for a document detailing the political traits of professors at the Academy of Music, compiled for the Ministry or a party organization. ${ }^{32}$ I also consulted her files at the Music Academy and the Serbian Academy of Sciences and Arts, and was fortunate enough to have a friend from Zagreb go to the Croatian State Archives and State Archives in Zagreb, where he found documents relating to one of the most difficult periods in Marićs life, when she spent several months in prison, accused of engaging in activities hostile to the state. Had I not received photocopies of those documents, this whole episode in my monograph would have been reduced to what I had read in an article by two musicologists from the Czech Republic and Austria,

\footnotetext{
30 Jim Samson, Chopin, Oxford, Oxford University Press), v.

31 Милин, љубица Марић, ор. cit., notes nos. 4 and 45.

32 Ibid., note no. 292.
} 
Vlasta Reittererova and Hubert Reitterer. ${ }^{33}$ Some of Ljubica's colleagues and contemporaries had some limited knowledge of this episode, but for ethical reasons I would not have relayed any of that without verification. It was a similar case with the stories one could hear among musical circles that Marić had a half-sister. Among the documents kept at the Archive of the Serbian Academy of Sciences and Arts there are documents that confirm that as well, which I included in my monograph in an abridged form. The same archive houses her correspondence (with the exception of a smaller portion, which is kept at the Archive of the Institute of Musicology), including that from the interwar period, which is especially interesting, because it offers a vivid psychological portrait of the young artist, who, despite living in extremely modest conditions and occasionally suffering from poor health, managed to achieve some major breakthroughs in her work.

Of course, one could question the relevance of these and similar pieces of information for a composer monograph. To be sure, one could not possibly link them to any of her works' characteristics, except in a rather indirect way. However, they do shed light on certain events that would come to affect her creative evolution. Regarding the episodes mentioned above, these pieces of information indicate the likely reasons behind her decision to leave Zagreb in 1936 and go to Prague for further study, which in turn put her on an even more direct path toward quarter-tone music. The same facts at least partly explain a drop in her production as a composer and even a total lack of new pieces during a certain period - in this case, in 1935. Answers to some other questions, although without written confirmation, may also be gleaned from biographical data. Thus, for instance, the stylistic turn in Marićs creativity that occurred between her works composed immediately after the war and Pesme prostora (Песме üpoc̄̄opa; "Songs of Space") is easier to understand if one is aware that in those years she invested a lot of her time in establishing friendships with prominent figures from artistic and intellectual circles, who provided her with new insights in numerous domains - the wealth of world cultures, including Serbian culture, as well as new, fresh artistic ideas and directions. I believe that it was precisely this kind of spiritual environment that gave rise to her heightened interest in tradition - the permanent values that the human spirit had created over the centuries and millennia - which then,

33 Vlasta Reittererova and Hubert Reitterer, "Musik und Politik - Musikpolitik. Die Internationale Gesellschaft für Neue Musik im Spiegel des brieflichen Nachlass von Alois Hába 1931-1938”, Miscellanea musicologica, XXXVI, 1999, 129-310. 
processed in her individual artistic manner, came to inform works such as

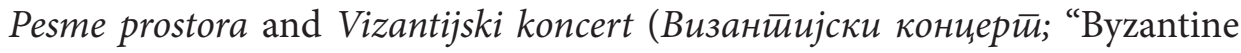
Concerto").

In terms of structuring the monograph, I thought about using a non-standard approach, which I had seen some years back in a book on Richard Wagner, ${ }^{34}$ written like a sort of encyclopaedia about the composer, with individual entries on each music drama and major writings, important figures in his life, the Bayreuth Festival, his revolutionary activities, etc. I devised a similar structure for my 'proto-monograph' on Marić - the catalogue for the exhibition at the Gallery of the Serbian Academy of Sciences and Arts (2009). The opening chapter takes the form of a "Dictionary", with subchapters on individual works, figures with whom she maintained important relationships, the cities she inhabited, and various terms such as "Byzantium" (Византиија), "Octoechos" (Осмоіласник), and "Prague Students" (ирраики $Ђ a \varkappa u)$, in which I sought to survey her activities from different perspectives.

When I later set out to write a 'real' monograph, I opted for a chronological narrative of the composer's life, complementing it where pertinent with analytical commentary on her pieces. I tried to tie those interpolations with surrounding texts as much as I could, but still without preventing the reader from consulting them separately. In the opening chapter to the second part of

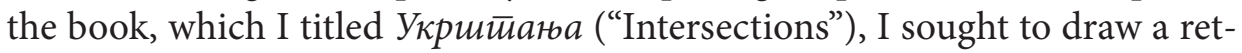
rospective, non-chronological link between her pieces from different periods in her life and shed light on them from the perspective of the relevant topics and preoccupations that permeate them. Thus I discussed the problematics of Marić's visions of Byzantium as her spiritual homeland, her creative treatment of the Octoechos, the philosophy of the time, and modernism as her main orientation.

Thus conceived and structured, my monograph about Ljubica Marić was intended to offer a comprehensive portrayal of the composer as a figure and creator in music, to intertwine my analyses of her music with various epistemological threads and discourses that might serve to construct her meanings. I think it would have been rather strange had I not included in the monograph the composer's own succinct and poetic commentaries about her works, because they point to the spiritual kernels that gave rise to her music. As one of the important contexts of her music, they may be crucial for

34 Unfortunately, I have no bibliographical data on this publication. [Maybe it's Jonathan Lewsey, Who's Who and What's What in Wagner (Routledge, 1997)?] 
understanding her individual pieces, whether as a whole or in detail. Had it not been for Marićs own statement that "a sound from without [the Sputnik satellite's radio signal] was directly transposed into the music [of her Passacaglia]", it would have been almost impossible to infer that from the music itself. On the other hand, it would have been easier to spot that a fragment from her Сйихови из Горскоі вијенца ("Verses from The Mountain Wreath") appeared in Торзо ("Torso"), her final piece, but her commentary on the piece confirms that this is indeed the case. Another expression of her need to direct the listener to something beyond the musical text itself appears in the motto heading her Ostinato super thema Octoïcha, a phrase resembling a riddle or

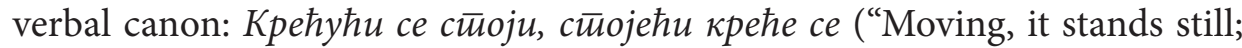
standing still, it moves"). In that way she sought - and was not alone in that sense - subtly to introduce the listener to the main idea, character, and atmosphere of the work and thereby offer her own interpretation of her artistic urge.

How successful I was in my attempt to integrate the composer's biography with her oeuvre in this monograph, in other words, whether the monograph is a successful hybrid of two books in one (as discussed by Jim Samson), will have to be judged by its reviewers and other readers. During my work on the book, I often thought of the musicologists who study or will study the oeuvre of Ljubica Marić, anticipating dialogues with them. I would like this monograph to act as a stimulus for new, undoubtedly different views of her work and activities, as well as to offer at least a modest impetus for extending or even intensifying the life of her music in concerts and sound recordings.

\section{Summary}

The status of composer monographs as a genre kept changing from the $19^{\text {th }}$ century to the present. While the romantic age, with its cult of genius, was dominated by an approach that placed too much weight on biographical facts, often without enough justification for drawing parallels with the composer's creative oeuvre, authors of monographs today clearly manifest their desire to survey the lives and works of composers in their complex inter-dependency, carefully examining their potential links.

The article sets out with a survey of monographs on Serbian composers in chronological order, beginning with Сйомениц а Сиевану Мокраницу ("A Memorial to Stevan Mokranjac") by Kosta Manojlović (1923), a work that is modest in scope but offers a comprehensive and expert survey of the composer's life, efforts, and importance. The rise of this genre in Serbian musicology could be seen in the post-WWII period, fea- 
turing important, often even model monograph studies: P. Konjovićs monographs on M. Milojević (1954) and St. Mokranjac (1956), V. Peričićs monographs on J. Marinković (1967) and St. Rajičić (1971), M. Bergamo’s monograph on M. Ristić (1977), N. Mosusova’s monograph on P. Konjović, and M. Veselinović Hofman's monograph on V. Radovanović (1991). The present century has seen the monographs of G. Pilipović on D. Radić (2000), E. Josif on M. Živković (2009), N. Sovtić on R. Brucci (2017), M. Milin on Lj. Marić (2018), and J. Mihajlović Marković on P. Milošević (2019).

In order to assess the achievements of these works in the context of monographs written elsewhere in the world, the article discusses the main features of the often ambivalent relationship of authors of monographs with biographical data in writers such as H. Danuser, C. Dahlhaus, M. Solomon, and some younger authors. The author of the article attaches special relevance to J. Samson's view that, although the desire to integrate the discussions of a composer's life and works is understandable, one should accept the hybrid character of the genre and its "duality", which he describes as "two books in one". 